\title{
How to Empower Machine-Translation-to-Web Pre-Editing From the Perspective of Grice's Cooperative Maxims
}

\author{
Chung-ling Shih \\ English Department, National Kaohsiung University of Science and Technology, Kaohsiung, Taiwan
}

\begin{abstract}
This article takes pre-editing to a new level, shifting its purpose from improving the linguistic accuracy of the machine-produced translation (MT) to boosting the communication effect of MT. Adopting the method of MT textual analysis, this research asked ten university students to read and assess two sets of MT versions generated from pre-edited and non-pre-edited texts retrieved from the web pages of five companies in Taiwan. Students were interviewed to express their preferences and make comments. The findings showed that $90 \%(9 / 10)$ of student respondents perceived the MT texts, which were generated from pre-edited text with a shorter length, as more communicative than the MTs produced from non-pre-edited texts. Additionally, $100 \%(10 / 10)$ of student respondents agreed that the MTs, which were generated from pre-edited texts with concise textual contents and thematic relevance to subheadings, were more communicative than the MTs produced from non-pre-edited texts. The respondents' feedbacks are compatible with Grice's maxims of quantity, quality, and relation. This article concludes by highlighting the new direction of revising the information amount, content, and thematic relevance of a web text, and supports extra-linguistic pre-editing from the perspective of Grice's cooperative maxims.
\end{abstract}

Index Terms-MT, pre-editing, quality maxim, quantity maxim, relation maxim

\section{INTRODUCTION}

The automated machine-created translation (MT) has become one of easily-accessed media of information transmission and communication globally. Particularly artificial intelligence (AI) technology empowers the neural MT system to help it produce the output with better quality and high comprehensibility. Due to this improvement, people start mulling whether pre-editing, which revises the source text to enhance the readability and comprehensibility of MT outputs, remains necessary. However, for real-time effective communication of web-based MT texts, there is much more than linguistic accuracy. Despite a great improvement in the linguistic rendering of current neural MT systems, there are other factors that can enhance the communication effect of MT and that we cannot overlook. We may push and move forward to think about what to tell and how much to tell in a web-based MT text. As an add-on, pre-editing for MT-to-Web needs to consider extra-linguistic factors and shifts its linguistic issue to communication concerns. The MT of web-based text can be reader-friendly or reader-appellative. Pre-editing can move beyond linguistic accuracy and pursues how to make the MT evoke web audiences' interest. This idea is borrowed from our daily communication in which we hope to be interested in what the addressor says besides easy comprehension. Simple, easy-to-understand words and simple sentence structures are generally perceived as essential requirements for MT. However, if the audience finds that the information in an MT text is not introduced clearly and logically, they would not accept it. To ensure the effective communication of an MT text, we can pre-edit the source text to make what is said and how it is said in the MT text attractive and comprehensible to web audiences.

Most of existing literature on pre-editing calls for adhering to the rules of conciseness, simplicity and flatness (Shih, 2020). The concise style requires the use of short sentences; the simplicity feature emphasizes the use of simple sentence structures, and the flatness trait asks for the use of words without local identity, words without multiple meanings, and words without vague and ambiguous meanings. While not denying the importance of linguistic accuracy through pre-editing, this article moves a step further. It concerns the content, the way of developing ideas, and the amount of information in a source text. Pre-editing can shift its focus from linguistic to communicative aspects with an aim to foster MT-mediated communication effect. To this end, this article explores how the MT outputs of a source text with and without pre-editing show different levels of communication in the areas of content, idea development and information amount. Grice's $(1975,1989)$ maxims of quality, quantity and relation are used as the theoretical framework to support research findings because they discuss how conversational communication between the addressor and the addressee can be optimized following some principles. In the similar fashion, pre-editing helps boost the communication effect of MT outputs if it complies with effective communication principles. Three research questions are raised for investigation.

(1) Why is the MT generated from a pre-edited text perceived as more communicative than that from the non-preedited text when examined from the information amount? 
(2) Why is the MT generated from a pre-edited text perceived as more communicative than that from the non-preedited text when examined from the content quality?

(3) Why is the MT generated from a pre-edited text perceived as more communicative than that from the non-preedited text when examined from the contextual structure?

Never is research on pre-editing strategies conducted from the perspective of Grice's (1975, 1989) cooperative maxims, so this article is a new attempt and opens up a new direction. The author asked ten student participants to assess the MTs of the source texts with and without pre-editing, and it was justified that the MT generated from a preedited text had a better communication effect.

\section{THEORY REVIEW}

\section{A. Pre-Editing}

Pre-editing is defined as "the process of preparing a source language (SL) for translation by a machine translation system" (Shuttleworth \& Cowie, 1997, p. 129). It is also seen as the process of revising a source text before it is rendered by an MT system (Melby, 1987). According to Carbonell \& Tomita (1987), the purpose of pre-editing is to "eliminate complex grammatical structures, ambiguous words and problematic nuances" (p. 72). In other words, the objective of pre-editing is to reduce the semantic vagueness of lexical items and the incorrectness of grammatical, syntactic structures.

Pre-editing often goes through the process of converting a natural language into a controlled language. A source text is revised using a simplified form of language based on some restrictions on lexicon, grammar and syntactic structures of the source text. The controlled language, as opposed to the natural language, refers to an artificial language that does not permit an erroneous expressive variation in sentence structures and semantic features. Arnold, et al. (1994) claimed that a controlled language referred to "a specially simplified version of a language" (p. 211), perceived as a partial solution to communication problems. In essence, it is a "variant of [source language] in which texts are composed according to a set of rules designed to enhance the clarity and readability of what is said" (Shuttleworth \& Cowie, 1997, p. 29). It uses "only a limited number of basic words (including a clearly circumscribed teaching vocabulary), each of which typically has only one meaning" (Shuttleworth \& Cowie, 1997, p. 30). In the MT context, it is "used as a means of improving the performance of machine translation systems" (Shuttleworth \& Cowie, 1997, p. 29). In order for the MT system to produce more correct multi-lingual outputs, weather bulletins, medical reports, UVI reports, traffic reports, business letters, product instructions, and automobile owners' manuals, to cite few, are often written using the controlled language.

International companies developed and implemented controlled language tools to perform pre-MT editing. European Association of Aerospace Industries developed AECMA Simplified English, and applied it in the aeronautic industry (Torrejón \& Rico, 2002). Boeing Company developed Boeing Technical English (BTE) and used it to restrict and unify the style of BTE texts. Caterpillar Inc., a heavy-equipment machinery manufacturer, developed Caterpillar Technical English (CTE) to assist in the translating of some documents (Torrejón \& Rico, 2002). General Motors conducted the Controlled Automotive Service Language project (CASL) in 1993. The Swedish manufacturer of trucks, Scannia, and BMW developed their own controlled language system for Swedish and German texts respectively (Torrejón \& Rico, 2002).

Over the past ten years, rapid technological advances in neural MT system have greatly improved linguistic accuracy of MT outputs. Thus, pre-editing has been less applied. However, the author thinks that for an online neural MT system to render the web text into multiple target languages, pre-editing remains useful in non-linguistic aspects. Since web audiences often scan or skim the web-based MT texts for desirable information, they care more about getting core messages immediately rather than the high level of linguistic accuracy. Thus, current pre-editing can make an alternation on its focuses, changing from previous linguistic areas to communicative and functional issues. This proposal is what the present article aims to promote.

\section{B. Theory of Grice's Cooperative Maxims}

Since this article supports the communication effect of the MT generated from a text with extra-linguistic pre-editing from the perspective of Grice's cooperative maxims, the important concepts of the theory need to be discussed at some length. Grice $(1975,1989)$ proposed the cooperative principle because the key to effective communication was commonly tailoring a message to the addressee's/receiver's need. To illuminate the cooperation principle, Grice (1975, 1989) raised four maxims--quantity, quality, relation and manner. The quantity maxim refers to the right amount of information input; the quality maxim means true information; the relation maxim suggests relevant information, and the manner maxim means a brief, clear and orderly presentation. The four maxims cover the scope of message, the source of the message, the content of the message and the way of presenting a message. The scope must be appropriate, neither too much nor too little. The information source must be true and, if needed, have the evidence. The content must be relevant to the topic or be treated as a relevant response. The way of presenting must be succinct, brief and orderly. In this research, only the maxims of quantity, quality and relation are used to support the communication effect of the MT generated from a pre-edited text. 
According to Grice $(1975,1989)$, too much information could cause a waste of time, but too little information will be informatively inadequate. The false information might offend the hearer and the unclear and illogical, ambiguous way of delivering the message will hinder the conversation from continuing. Additionally, the speaker and the hearer must move toward a mutually accepted goal or follow the same direction in their talk; otherwise their information is not related to the shared topic and cannot move on.

Green (1996) pointed out that Grice's (1975, 1989) cooperative maxims had been overrated as the common assumptions for all speakers in the world without paying attention to intercultural difference or diverse ways of communication. The author agrees to this point and argues that no theory can be generalized to cover all individual instances. Partial modification is needed when a theory is replicated in a different study. Thus, adopting Grice's (1975, 1989) cooperative maxims to discuss MT-enabled communication, the author has raised some modification.

In the area of information amount, Grice's $(1975,1989)$ maxim of quantity is applicable without adaptation. In each act of communication, a wordy text or talk is often boring to the reader and the hearer. Many people feel it is a waste of time to read a long text for information scanning or skimming. Particularly web audiences are eager to get the main idea or the gist of a text within a short time. Thus, the rule of neither too much nor too little information is used to examine the pre-editing of textual length. Regarding textual content, Grice's $(1975,1989)$ maxim of quality needs to be modified. In the conversation situation, Grice $(1975,1989)$ asked the addressor to provide true information with reliable resources. For web audiences, instead of genuine, reliable information, the important and interesting information is what they are more concerned about. Thus, when it is used to support pre-editing function, Grice's $(1975,1989)$ maxim of quality is modified as important and intriguing information.

In the aspect of thematic relevance, Grice's $(1975,1989)$ maxim of relation emphasizes relevance to immediate needs in the process of interaction. This means that the addressor needs to consider what the addressee expects to hear from the talk and the information must be relevant to the topic they are talking. In the context of pre-editing, the MT text expects to convey messages in a well-organized way, so Grice's $(1975,1989)$ maxim of relation can be adjusted from relevance to the addressor's immediate needs to informative relevance to thematic subheadings. The modified maxim of relation refers to the thematic relevance of information as the guidance for pre-editing. Overall, Grice's (1975, 1989) discussion is set within the context of conversation, but our discussion is put within the MT context, so the maxims of quantity, quality and relation need adjustments to fit pre-editing in the present research.

\section{METHODOLOGY}

\section{A. Collected Data}

Some passages extracted from the web-based texts of five Taiwan's companies are collected, including Chinese Petroleum Corporation (CPC) (2013), Asogroup Com. (2011), ASUSTeK Computer Inc. (2016), The Grand Hotel (2018) and Ten Ren Tea Co. Ltd.(2021). All collected texts are used for pre-editing. The focuses of pre-editing include (1) shortening the length of the text, (2) removing redundant, unimportant information, and (3) adding subheadings and relating information to the subheading. The three areas of pre-editing are kept in line with Grice's $(1975,1989)$ maxims of quantity, quality and relation.

Two MT versions of the text with and without pre-editing are collected for a comparison. The neural MT system, DeepL, is used to generate English translation from Chinese. DeepL is chosen because it hails itself as the world's most accurate translator on the web through an assessment of English-to/from-Germany, English-to/from-French and English-to/from-Spanish MT outputs generated by DeepL, Google, Amazon and Microsoft (Deepl. Com., n.d.).

\section{B. Research Methods}

This research adopts a mixed-method approach consisting of MT textual analysis and informal interview. The communication effect of two MT versions of the same source text with and without pre-editing were analyzed and assessed by student participants, who were English majors. These students volunteered to help assess the English MT texts. Eight females and two males were included, and their English proficiency was beyond the B1 level (550 scores) of the Test of English for International Communication (TOEIC). All participants received informal interviews through their verbal consent.

The entire MT text is used as an assessment unit because web audiences often read an MT text to get its gist or its core messages. The participants revealed their views after a comparison of two MT versions. They informed which MT version they thought was more communicative in terms of textual length, content quality and idea development. Additionally, they commented why they favored one version over the other. They were advised to overlook lexical, syntactic and grammatical errors because the assessment in this research did not focus on linguistic accuracy of MT. The participants' feedback after reading two sets of MT versions of five texts was provided to the authors during informal interviews.

\section{FINDINGS AND DisCUSSION}

\section{A. Pre-Editing Textual Length to Produce More Communicative MT}


In response to RQ1, the findings showed the MT generated from the shorter, pre-edited text was perceived as more communicative than the MT produced from the longer, non-pre-edited text. Nine out of ten (90\%) student respondents favored the MT generated from the shorter, pre-edited text over the MT produced from the longer, non-pre-edited text. The consensus the student respondents had reached was that a shorter MT version could reduce their effort and time for reading. Table 1 shows two MTs of a passage retrieved from the CPC text with and without pre-editing.

TABLE 1

Two MTs Of A PAssage From The CPC TEXT With AND Without PRE-EDITING

\begin{tabular}{|c|c|}
\hline Source Text without Pre-editing & MT1 \\
\hline $\begin{array}{l}\text { 本公司產製高品質的優良油品, 火炬商標早已受到國人的信 } \\
\text { 賴. 品質第一是信守不渝的經營理念。未本更應加強品質管 } \\
\text { 理致力提昇國人生活環境的品質。本公司肩負國家多項任 } \\
\text { 系分供應各行業用油是本公司重要職責之一; 油品市場 } \\
\text { 自後, 為了市場占有率, 如 : 特務經營更著力的工於銷售服務 } \\
\text { 油服務及用油技術的指導, 對第一線 } \\
\text { 油品銷售人員的服務水準與態度更為要求, 以落實服務至上 } \\
\text { 的經營理念, 繼續維繫市場「領導」品牌於不墜。(Chinese } \\
\text { Petroleum Corporation, 2013) }\end{array}$ & $\begin{array}{l}\text { Our company produces high quality oil products, and the Torch trademark has } \\
\text { long been trusted by the people of China, and quality is our business } \\
\text { philosophy. In the future, we should strengthen the quality management and } \\
\text { strive to improve the quality of the living environment of the nation. Our } \\
\text { company is responsible for many national tasks, and supplying oil for all } \\
\text { industries is one of our important responsibilities. After the liberalization of } \\
\text { the oil market, in order to gain market share, our business operation is more } \\
\text { focused on the sales and service side. For example: special industrial oil } \\
\text { service and oil technology guidance, the service standard and attitude of the } \\
\text { front-line oil sales staff are more demanding, in order to implement the } \\
\text { business philosophy of service first, and continue to maintain the "leading" } \\
\text { brand in the market without falling. (139 wds) }\end{array}$ \\
\hline Source Text with Pre-editing & MT 2 \\
\hline 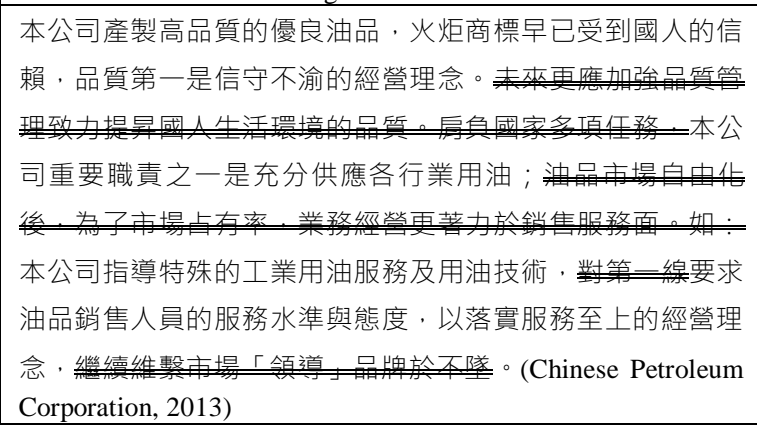 & $\begin{array}{l}\text { Our company produces high quality oil products and the Torch trademark has } \\
\text { long been trusted by the nation. Quality first is our business philosophy. One } \\
\text { of the important responsibilities of our company is to fully supply oil for all } \\
\text { industries; our company instructs special industrial oil service and oil } \\
\text { technology, and requires the service standard and attitude of oil sales staff to } \\
\text { implement the business philosophy of service first. ( } 69 \text { wds) }\end{array}$ \\
\hline
\end{tabular}

As shown above, the length of MT2 produced from the pre-edited text is 69 words, as opposed to 139 words of MT1 generated from the non-pre-edited text. Most students were positive about MT2, expressing that the shorter MT version contained the lower amount of information, so it sped up their reading. One student respondent claimed that she did not care about the detailed information when skimming a web text. A couple of student respondents revealed that they did not have patience to read the details, so the shorter, the better. They thought that some statements, e.g., "In the future, we should strengthen the quality management and strive to improve the quality of the living environment of the nation," and "Our company is responsible for many national tasks," were redundant and could be eliminated. Without the information, they still could understand clearly the business philosophy of CPC - the strong commitment to the production of good-quality oil for the country. Contrary to most respondents' view, another student respondent insisted that detailed information should be retained, so she could understand better the business value and contributions of CPC.

Many student respondents' preference for the shorter MT version suggests that web audiences in general favor a shorter text because it can reduce their cognitive load of reading the web text. This point concurs with Grice's (1975, 1989) proposal of the quantity maximum that urges the addressor to use neither too much nor too little information in the process of information exchange. The current Chinese web texts addressing domestic companies tend to use overlapping information, so they can be revised.

\section{B. Pre-Editing Textual Content to Produce More Communicative MT}

In answer to RQ 2, the findings showed that the MT produced from the pre-edited text that carried only key information was perceived as more communicative than the MT generated from the non-pre-edited text. All ten student respondents (100\%) favored MT2 generated from the text whose content was pre-edited over MT1 produced from the text whose content was not pre-edited. It was agreed that MT2 highlighted the important and intriguing information, so it attracted audiences' attention and interest. Table 2 shows the two MTs of a passage extracted from the web-based text of Asogroup Com. (abbreviated as ASO) with and without pre-editing. 
TABLE 2

Two MTs Of A PASSAGE From THE ASO TEXT With AND WITHOUT PRE-EDITING

\begin{tabular}{|c|c|}
\hline Source Text without Pre-editing & MT1 \\
\hline 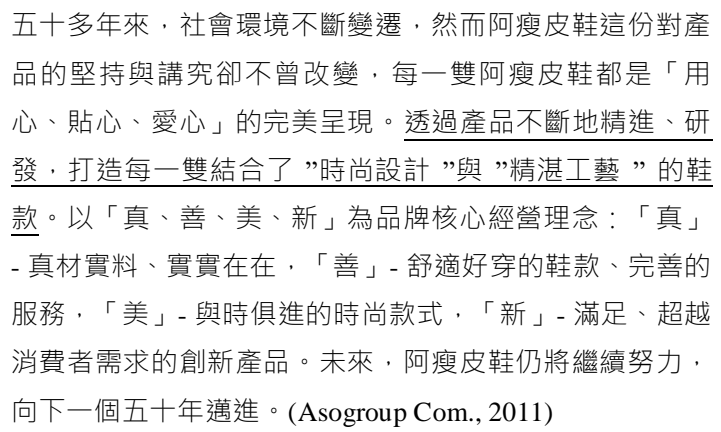 & $\begin{array}{l}\text { The social environment in Taiwan has changed a lot in the past } 50 \text { years, but our } \\
\text { persistence and efforts have not changed at all. Our shoes represent our } \\
\text { sincerity, thoughtfulness and love. Through continuous improvement and } \\
\text { research, our shoes combine fashionable design with excellent skills. "True, } \\
\text { Good, Beautiful, New" is our key business philosophy. "Truth" means genuine } \\
\text { materials and solid work. "Goodness" means comfortable shoes and perfect } \\
\text { service; "beauty" means ever-evolving styles; "newness" means ever-innovating } \\
\text { products to meet customer needs. We will continue to work hard to move into } \\
\text { the next } 50 \text { years.( } 93 \text { wds) }\end{array}$ \\
\hline Source Text with Pre-editing & MT 2 \\
\hline 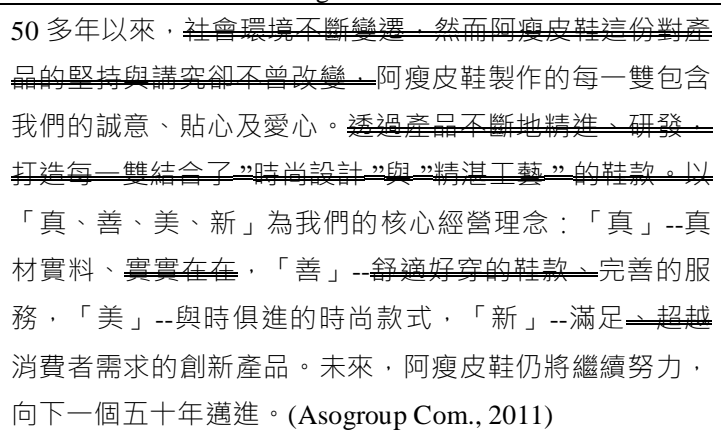 & $\begin{array}{l}\text { For more than } 50 \text { years, each pair of leather shoes made by A-Skinny has } \\
\text { contained our sincerity, thoughtfulness and love. Our core business philosophy } \\
\text { is "Truth, Goodness, Beauty, and Newness": "Truth" -- genuine materials, } \\
\text { "Goodness"-- perfect service, "Beauty" -- fashionable styles that keep up with } \\
\text { the times, and "Newness"-- innovative products that meet consumer needs. In } \\
\text { the future, A-Skin will continue to strive for the next fifty years.(70 wds) }\end{array}$ \\
\hline
\end{tabular}

Being asked the reason for her preference for MT2, one student respondent expressed that the key points of the text, namely the business philosophy of ASO, appeared immediately after the beginning sentence, so it attracted her interest. In contrast, when the same message was shown after three long sentences in MT1, it had downplayed its importance and could not evoke her interest. Another student respondent who had the similar view claimed that she needed to decode the meanings of the first three long sentences before she caught the core message of ASO business philosophy of "Truth, Goodness, Beauty, and Newness". Several students agreed that the redundant information, e.g., "Through continuous improvement and research, our shoes combine fashionable design with excellent skills," distracted their attention from the core message of the business philosophy of ASO.

We may examine how students respond to another example that is the MT of a passage extracted from the web text of The Grand Hotel (abbreviated as TGH). Table 3 shows the two MTs of a passage with and without pre-editing.

TABLE 3

Two MTs Of A PASSAge From The TGH TeXT With AND Without PRE-EDITING

\begin{tabular}{|c|c|}
\hline Source Text without Pre-editing & MT1 \\
\hline $\begin{array}{l}\text { 圓山飯店創立於民國 } 41 \text { 年 (西元 } 1952 \text { 年) , 十四層宮殿 } \\
\text { 式大樓, 巍峨高循於圓山之腰, 前臨基隆河、後倚陽明 } \\
\text { 山、東望松山、西眺淡水。飯店紅柱金瓦氣勢宏偉的外 } \\
\text { 觀, 儭托富麗堂皇的古典氣氛, 傳達了中國的藝術之美, } \\
\text { 是台北市的代表地標之一, 聞名世界。是中外人士觀光住 } \\
\text { 宿或商務會議的最佳選擇。(The Grand Hotel,2018) }\end{array}$ & $\begin{array}{l}\text { Founded in 1952, the 14-story palace-style building towers over the waist of } \\
\text { Yuanshan Mountain, facing the Keelung River, leaning against Yangmingshan } \\
\text { Mountain, looking east at Songshan Mountain and west at Danshui. The hotel's } \\
\text { magnificent outlook with red pillars and golden tiles, set against the magnificent } \\
\text { classical atmosphere, conveys the beauty of Chinese art and is one of the } \\
\text { representative landmarks of Taipei City and is known worldwide. It is the best } \\
\text { choice for sightseeing and business meetings for Chinese and foreigners. }\end{array}$ \\
\hline Source Text with Pre-editing & MT 2 \\
\hline 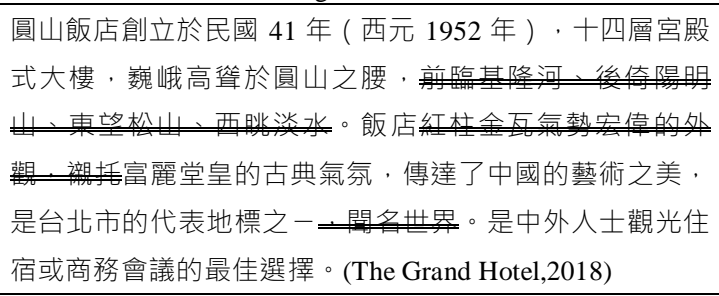 & $\begin{array}{l}\text { Founded in 1952, the 14-story palace-style building towers over the Yuanshan } \\
\text { Mountain. It is one of the representative landmarks of Taipei City, with a } \\
\text { magnificent classical atmosphere that conveys the beauty of Chinese art. It is the } \\
\text { best choice for sightseeing and business meetings for Chinese and foreigners. }\end{array}$ \\
\hline
\end{tabular}

With the same results as student responses to the example shown in Table 2, all student respondents favored MT 2 produced from the pre-edited text, which preserved only important and significant information, over MT 1 generated from the non-pre-edited text. A couple of student respondents reached an agreement that without unnecessary information. e.g., "facing the Keelung River, leaning against Yangmingshan Mountain, looking east at Songshan Mountain and west at Danshui," and "magnificent outlook with red pillars and golden tiles," MT2 allowed them to 
concentrate their attention on the most important information of "the 14-story palace-style building towers over the Yuanshan Mountain". On the contrary, MT1 provided redundant information to make the key message off focus and so reduced the audience's interest. One student maintained that the web text with only meaningful and significant information, as exemplified by MT2, intrigued him and motivated him to read the text. Another student noted that the loud statement "is known worldwide" exaggerated the fact, so he disliked MT1.

Student respondents' overwhelming preference for MT2 brings into light that the MT text that conveys key and interesting information without miscellaneous, exaggerative information can trigger the reader's interest. Most web audiences scan web texts first and then determine if the texts are worth close reading. Thus, the quality of the content of the web text is a key factor to affect web audiences' choice of reading it or not. The respondents' comments concur with Grice's $(1975,1989)$ maxim of quality. As the addressee regards conveyed information as false and then discontinues conversation in Grice's $(1975,1989)$ communication context, the audiences who scan MT texts lose their interest when they find that the MT cannot immediately attract their attention and interest.

\section{Pre-Editing Contextual Structure to Produce More Communicative MT}

In reply to RQ 3, the findings showed that the MT produced from the pre-edited text, which added thematic subheadings and related information to the specific themes, were accepted as more communicative than the MT generated from the non-pre-edited text. All student respondents $(100 \%, 10 / 10)$ favored MT2 generated from the text, whose presentational way emphasized thematic relevance to subheadings, over MT1 produced from the text whose way of information presentation was not logical. Table 4 shows the two MTs of a passage extracted from the web-based text of Ten Ren's Tea (abbreviated as TRT) with and without pre-editing.

TABLE 4

Two MTs Of A PASSAGE From THE TRT TEXT WITH AND Without PRE-EDITING

\begin{tabular}{|c|c|}
\hline Source Text without Pre-editing & MT1 \\
\hline $\begin{array}{l}\text { 以『老行業, 新經營』的精神, 天仁致力於產品創新、通 } \\
\text { 路創新及組織創新, 除了將商品以茶為核心向各類型食品 } \\
\text { 發展外, 也開發「喫茶趣」( cha FOR TEA) 複合式餐飲 } \\
\text { 連鎖系統, 以追求茶葉國際化、生活化、年輕化的目標。 } \\
2003 \text { 年天仁授權美國可口可樂公司生產烏龍茶、綠茶飲 } \\
\text { 料, 創下國內傳統產業跨國性策略聯盟的典範。秉持「天 } \\
\text { 然、健康、人情味」的經營理念, 天仁購物網結合實體通 } \\
\text { 路的優勢, 提高服務品質, 以踏實經營為原則, 顧客滿意 } \\
\text { 為目標, 逐步的實現「有足跡的地方, 就有天仁苔茶」。 } \\
\text { 茶是天然、和平的飲料。創造更和諧、健康的社會與生活 } \\
\text { 環境, 將是天仁永遠追求的目標。 (Ten Ren Tea Co. } \\
\text { Ltd.,2021) }\end{array}$ & $\begin{array}{l}\text { With the spirit of "old industry, new management", Tianren is committed to } \\
\text { product innovation, channel innovation and organizational innovation. In } \\
\text { addition to developing products with tea as the core to various types of food, it } \\
\text { also develops the "cha FOR TEA" complex -Style restaurant chain system, in } \\
\text { order to pursue the goal of internationalization, life and youth of tea. In } 2003 \text {, } \\
\text { Tianren authorized the American Coca-Cola Company to produce oolong tea } \\
\text { and green tea beverages, setting a model for the multinational strategic alliance } \\
\text { of domestic traditional industries. Adhering to the business philosophy of } \\
\text { "Natural, Healthy, and Humane", Tianren Shopping Network combines the } \\
\text { advantages of physical channels to improve service quality, based on the } \\
\text { principle of pragmatic operation and customer satisfaction as the goal, and } \\
\text { gradually realizes "Where there is a footprint, there is Tianren "Mingcha". Tea is } \\
\text { a natural and peaceful drink. Creating a more harmonious and healthy society } \\
\text { and living environment will be the goal that Tianren will always pursue. }\end{array}$ \\
\hline Source Text with Pre-editing & MT 2 \\
\hline $\begin{array}{l}\text { 經營理念 } \\
\text { 天仁追求自然、健康與人情味的生活。我們的原則是誠實 } \\
\text { 的操作且我們的主要關注是顧客的滿意度。我們想要創造 } \\
\text { 和諧的社會與健康的生活環境。我們最終的目標是擴展我 } \\
\text { 們的分店, 故我們能夠在世界各地服務客戶。 } \\
\text { 創新業績 } \\
\text { 我們致力於產品的創新、行銷的創新與組織的創新如下: } \\
\text { 1)我們商品以茶為核心, 向各類型食品發展。 } \\
\text { 2)我們發展 food \& drink 連鎖系統, 名為 Cha For Tea。我 } \\
\text { 們已變成更國際化、更年輕及更友善使用者的公司。 } \\
\text { 3)在 } 2003 \text {, 我們授權美國 Coke-Cola 公司生產烏龍茶與綠 } \\
\text { 茶, 創下國內傳統產業跨國性策略聯盟的典範。(Ten Ren } \\
\text { Tea Co. Ltd.,2021) }\end{array}$ & $\begin{array}{l}\text { Business philosophy } \\
\text { Tianren pursues a natural, healthy and humane life. Our principle is honest } \\
\text { operation and our main concern is customer satisfaction. We want to create a } \\
\text { harmonious society and healthy living environment. Our ultimate goal is to } \\
\text { expand our branches, so we can serve customers all over the world. } \\
\text { Innovation performance } \\
\text { We are committed to product innovation, marketing innovation and } \\
\text { organizational innovation as follows: } \\
\text { 1) Our products take tea as the core and develop into various types of food. } \\
\text { 2) We develop a food \& drink chain system called Cha For Tea. We have } \\
\text { become a more international, younger and user-friendly company. } \\
\text { 3) In } 2003 \text {, we authorized the American company Coke-Cola to produce oolong } \\
\text { tea and green tea, setting a model for the multinational strategic alliance of } \\
\text { domestic traditional industries. }\end{array}$ \\
\hline
\end{tabular}

Many students were of the opinion that the contextual organization in MT2 helped them comprehend the messages easily and clearly. When they saw the subheading "Innovation performance" that indicated the theme of the business achievements of Ten Ren's Tea, they prepared for getting the information regarding the objectives the company had achieved over the past several years. In this way, they got the gist and understood the thematic messages easily. In contrast, MT1 had all information grouped together without thematic distinction, so it caused them to have difficult comprehension. 
One student respondent pointed out that in MT1, the first sentence singled out the company's innovation philosophy, but the subsequent sentences did not introduce how the company enforced the philosophy. The other student respondent expressed that in MT1, the sentence that addressed the company's achievements, e.g., "In 2003, Tianren authorized the American Coca-Cola Company to produce oolong tea and green tea beverages, setting a model for the multinational strategic alliance of domestic traditional industries" was mixed with the sentence that presented the company's innovation commitment, e.g., "In addition to developing products with tea as the core to various types of food, it also develops the "cha FOR TEA" complex-Style restaurant chain system." This contextual structure caused the MT text to be thematically confusing. Furthermore, the sentence, "Tea is a natural and peaceful drink" , was irrelevant to the sentences that came before and after it. Another student respondent commented that as opposed to MT1, MT2 was wellorganized by providing two subheadings "business philosophy" and "innovation performance", and grouping relevant information together under the two subheadings. This organizational way allowed him to understand the context easily.

The above example suggests that if all ideas are organized with thematic relevance to specific subheadings, they would be easily understood. The student respondents' comments concur with Grice's $(1975,1989)$ modified maxim of relation. The findings are supported by Strawson's (1964) argument that relevance in human communication is a common shared principle because "stating is not a gratuitous and random human activity" (p. 92). All given information is required to be relevant to the thematic topic (Wislon, 1998; Reinhart, 1981) and the greater the relevance of the information input, the smaller the processing effort is needed on the receiver/hearer. In the same vein, MT2 showcases a higher degree of thematic relevance than MT1, so it is more easily comprehended with less cognitive effort.

At this point, it is concluded that in addition to textual length, textual content, the way to present ideas or the way information is introduced is not of less importance. Pre-editing should give equal attention to the above three extralinguistic areas to generate a more communicative MT text.

\section{CONCLUSION}

This article presents the case study of the MTs of company texts with and without pre-editing in the areas of textual length, content, and textual structure to justify the strength of extra-linguistic pre-editing. While not denying the effectiveness of improving semantic, syntactic, grammar accuracy of MT outputs through pre-editing in existing literature, this article proposes an add-on direction-to focus pre-editing on extra-linguistic areas of a web text to optimize the communication effect of MT. The results of a comparative assessment on two sets of MT versions by university students have justified the communication effectiveness of extra-linguistic pre-editing. The present article takes on some research significance as follows.

- The existing literature of pre-editing never touches on extra-linguistic adaptation. In a different manner, this article shows that pre-editing can be done on the content, information amount and thematic relevance to enhance the communication effect of MT.

- MT and pre-editing is never probed from the perspective of Grice's $(1975,1989)$ cooperative maxims, so this article is a new attempt and opens up a new direction in the study of pre-editing.

- To optimize the MT-mediated web-based communication, pre-editing can move beyond the linguistic issue and consider how to increase web audiences' interest by meeting the extra-linguistic expectations.

This article concludes by calling for pre-editing a web text into a more communicative one with the appropriate amount of information, meaningful content, and thematic relevance. Pre-editing in the future can move towards a new path it did not take before when faced with the increasing linguistic accuracy of MT outputs generated by an advanced neural MT system, which is accessible for free on the web.

\section{REFERENCES}

[1] Arnold, D. J., et.al. (1994). Machine translation: an introductory guide. Blackwells.

[2] Asogroup Com. (2011). Gongsi yange [Company history]. Retrieved May 2, 2021 from http://www.asogroup.com.tw/aboutUs.aspx
ASUSTeK Computer Inc. (2016). Pinpai gushi $\quad$ [Brand $\quad$ story]. $\quad$ Retrieved May $3, \quad 2021$ from

[3] ASUSTeK Computer Inc. (2016). Pinpai gushi [Brand story]. Retrieved
https://tutorial.jumpdesign.tw/portfolio/w_15/about.html

[4] Carbonell, J. G., \& Tomita, M. (1987). Knowledge-based machine translation, the CMU approaches. In S. Nirenburg (Ed.), Machine translation: theoretical and methodological issues (pp. 68-89). Cambridge University Press.

[5] Chinese Petroleum Corporation. (2013). Gongsi jianjie [Company profile]. Retrieved May 4, 2021 from https://052244023.tw66.com.tw/

[6] Deepl.Com. (n.d.). Women yu jingzheng duishou xiang bi ruhe? [How do we compete with other companies?] Retrieved July 23, 2021 from https://www.deepl.com/quality.html.

[7] Grice, H. P. (1989). Studies in the way of words. Harvard University Press.

[8] Grice, H. P. (1975). Logic and conversation. In P. Cole \& J. L. Morgan (Eds.), Syntax and semantics, Vol. 3 (pp. 41-58). Academic Press.

[9] Melby, A. K. (1987). On human-machine interaction in translation. In S. Nirenburg (Ed.), Machine translation: theoretical and methodological issues (pp. 145-154). Cambridge University Press

[10] Reinhart, T. (1981). Pragmatics and linguistics: an analysis of sentence topics. Philosophica, 27(1), 53-93.

[11] Shih, C. L. (2020). Translation technology: development and application. Bookman Company. 
[12] Shuttleworth, M., \& Cowie, M. (1997). Dictionary of translation studies. St. Jerome Publishing.

[13] Strawson, P. F. (1964). Identifying reference and truth-values. Theoria, 30(2), 96-118.

[14] Ten Ren Tea Co., Ltd. (2021). Jituan jianjie [Group profile]. Retrieved May 4, 2021 from https://www.tenren.com.tw/Content/Messagess/contents.aspx?SiteID=10\&MmmID=654050560505345200

[15] The Grand Hotel (2018). Yuanshan Jianjie [Yuanshan profile]. Retrieved June 4, 2021 from https://www.grandhotel.org/TW/official/about.aspx?gh=TP

[16] Torrejon, E., \& Rico, C. (2002). Controlled translation: a new teaching scenario tailor-made for the translation industry. In Proceedings of the 6th EAMT workshop - teaching machine translation (pp. 107-116). Centre for Computational Linguistics, UMIST.

[17] Wilson, D. (1998). Discourse, coherence and relevance: a reply to Rachel Giora. Journal of Pragmatics, 29(1), 57-74.

Chung-ling Shih is a professor teaching translation in the Department of English and the MA Program of Translation and Interpretation at National Kaohsiung University of Science and Technology, Taiwan. Her research interest includes machine translation, culture studies, and translation theories. She published a book entitled Translation Technology: Development and Application in 2020 in Taiwan, expecting to share her MT teaching experiences with the public. 